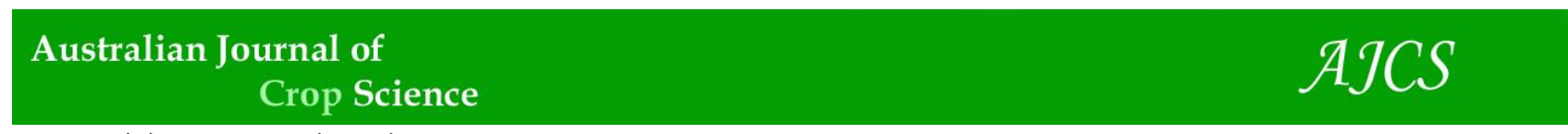

AJCS 10(7):1015-1021 (2016)

ISSN:1835-2707

DOI: 10.21475/ajcs.2016.10.07.p7693

\title{
Occurrence of Pseudomonas syringae pv. garcae in coffee seeds
}

\section{Leônidas Leoni Belan, Edson Ampélio Pozza*, Marcelo Loran de Oliveira Freitas, Melina Korres Raimundi, Ricardo Magela de Souza, José da Cruz Machado}

\author{
Federal University of Lavras, Department of Plant Pathology, Laboratory of Epidemiology and Plant Disease \\ Management, Lavras - MG, 37200-000, Brazil
}

*Corresponding author: edsonpozza@gmail.com

\begin{abstract}
Given the damage and losses caused by bacterial blight of coffee (Pseudomonas syringae pv. garcae) (PSG) in coffee (Coffea arabica) seedling nurseries and lack of knowledge of the origin of the initial inoculum, the goal of this study was to determine whether coffee seeds can contain viable inoculum and spread bacterial inoculum. Seeds from plants with symptoms of bacterial blight of coffee were immersed in sterilized saline solution, and the crude extract obtained was inoculated in leaves of coffee seedlings. Leaves of plants inoculated with seed extract from symptomatic plants had symptoms of bacterial blight similar to those on leaves inoculated with reference isolate PSG. Seedlings inoculated with seed extract from asymptomatic plants showed no symptoms. Symptomatic leaves were submitted to exudate tests, and the etiologic agent was isolated in culture medium. The isolates with colonies morphologically similar to reference isolate PSG were selected and tested for hypersensitive reaction (HR) and pathogenicity to coffee seedlings. The isolates positive for HR and pathogenic to coffee also showed biochemical and molecular patterns equal to those of reference isolate PSG by the rep-PCR technique using Box primer. Thus, coffee seeds from plants with symptoms of bacterial blight can contain viable inoculum of $P$. syringae pv. garcae.
\end{abstract}

Keywords: Bacterial blight; Coffea arabica; initial inoculum; seedling nursery; seed health.

Abbreviations: CFU_Colony forming units; HR_hypersensitive reaction; PC_Pseudomonas cichorii; PSG_Pseudomonas syringae pv. garcae; PST_Pseudomonas syringae pv. tabaci; UPGMA_method with arithmetic mean algorithm.

\section{Introduction}

Bacterial blight of coffee (Pseudomonas syringae pv. garcae Young, Dye \& Wilkie) (Amaral et al., 1956) has been causing damage in the major coffee growing regions worldwide, as it affects the crop in different stages of growth, from seedlings to plantations. The result is a significant reduction in production from the seedling and in final crop yields. Furthermore, disease control is difficult after the occurrence of the disease in plants in the nursery or plantation because of the high rate of disease progression and low chemical control efficiency (Zoccoli et al., 2011; Rodrigues et al., 2013). Seedling density in nurseries provides favorable conditions for disease development, as direct contact between leaves of susceptible host plants associated with excess moisture in the environment favor pathogen spread and occurrence of epidemics. Thus the occurrence, distribution pattern and progress of epidemics depend on the origin of the initial inoculum, which is often seed borne (Romeiro, 2005; Brasil, 2009). Several studies have provided evidence that seeds harbor diverse microbial flora, both on the surface and in the internal tissues (Saettler et al., 1989; Bacilio-Jiménez et al., 2001; Romeiro, 2005; Goto, 2012; Silva et al., 2013), and proliferation is stimulated in early germination (Simon et al., 2001; Nelson, 2004). In the case of plant pathogens, the inoculum can be transmitted by seeds to plants in both nursery and field. Even harbored in the outer seed integument, the inoculum of some bacterial species can cause infection in plants (Guthrie, 1970; Silva et al., 2002; Corrêa et al., 2008). Silva et al. (2013) reported transmission and infection by Xanthomonas vesicatoria from seed integument to new shoots of tomato seedlings (Solanum lycopersicum L.). Although seed transmission rate is low (Saettler et al., 1989; Carmo et al., 2004), seeds can act as efficient vectors for spreading bacteria (Romeiro, 2005) if the initial inoculum is introduced into growing areas (Carmo et al., 1996; Carmo et al., 2004; Romeiro, 2005; Silva et al., 2013). For example, the transport of bacteria from complex $X$. vesicatoria by tomato seeds ( $S$. lycopersicum) is a major mechanism of survival and spread of the pathogen (Carmo et al., 2004; Jones et al., 2004). Thus, seed-borne bacteria can be efficiently disseminated over long distances and introduced in areas free of disease, or may serve as a source of initial inoculum for epidemics in nurseries and fields (Neergaard, 1979; Romeiro, 2005). Therefore, seed health is especially important for disease management. Given the damage and losses caused by bacterial blight of coffee in seedling nurseries, and a lack of knowledge of the origin of the initial inoculum, the goal of this study was to determine whether coffee seeds can contain viable inoculum and spread the inoculum of $P$. syringae pv. garcae.

Results

Symptoms of bacterial blight on coffee seedling leaves

There were no symptoms in seeds from symptomatic plants. Ten days after inoculation there were typical symptoms of bacterial blight of coffee in leaves of seedlings inoculated with seed crude extract from symptomatic plants (Fig. 1 C). 
Table 1. Results of biochemical and pathogenicity tests of bacterial isolates from coffee seeds and reference isolates of genus Pseudomonas

\begin{tabular}{|c|c|c|c|c|c|c|c|}
\hline \multirow{2}{*}{ Tests* } & & \multicolumn{6}{|c|}{ Isolate } \\
\hline & PST & $\mathrm{PC}$ & PSG & B1 & $9 \mathrm{P}$ & $10 \mathrm{P}$ & $12 \mathrm{P}$ \\
\hline Gram & - & - & - & - & - & - & - \\
\hline Anaerobiosis & + & + & + & + & + & + & + \\
\hline Oxidase & - & + & - & - & - & - & - \\
\hline Gelatin hydrolysis & + & - & + & + & + & + & + \\
\hline Fluorescent pigment production & + & + & + & + & + & + & + \\
\hline Hypersensitivity on tobacco leaves & + & + & + & + & + & + & + \\
\hline Hypersensitivity on tomato leaves & + & + & + & + & + & + & + \\
\hline Hypersensitivity on kale leaves & + & + & + & + & + & + & + \\
\hline Hypersensitivity on bell pepper leaves & + & + & + & + & + & + & + \\
\hline Reproduction of symptoms on coffee leaves & + & + & + & + & + & + & + \\
\hline
\end{tabular}

*Described by Lelliott et al. (1966), Wilkie and Dye (1973), Rodrigues Neto et al. (1981), Schaad et al. (2001) and Maringoni (2010). PST, PC and PSG: respectively, isolates Pseudomonas syringae pv. tabaci (IBSBF 2249), P. cichorii strain pathotype (CFPB 2101) and P. syringae pv. garcae strain pathotype (CFPB 1634) used as reference standards. B1, 9P, 10P and 12P: bacterial isolates from coffee seeds (Coffea arabica L.). (+) Test positive reaction, (-) Test negative reaction.

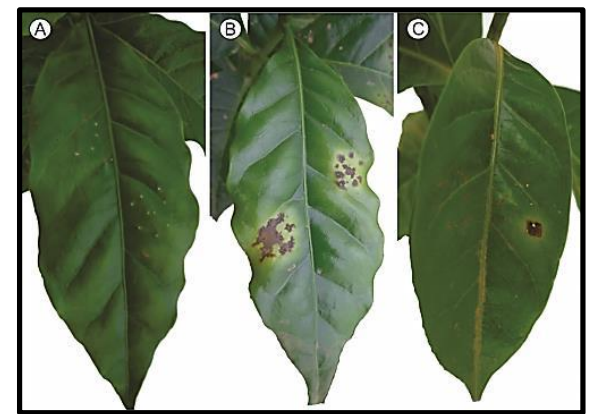

Fig 1. Symptoms on coffee leaves 10 days after inoculation of: (A) crude extract of seeds from asymptomatic plants using multineedle equipment; (B) reference isolate Pseudomonas syringae pv. garcae strain pathotype (CFPB1634); and (C) seed crude extract from plants with symptoms of bacterial blight of coffee.
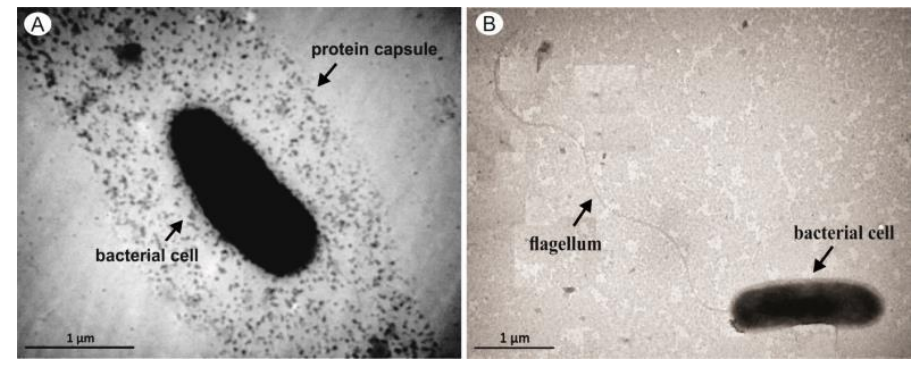

Fig 2. Transmission electron microscopy images of bacterial cells from Pseudomonas syringae pv. garcae: (A) Rod-shaped bacterial cell with protein capsule; (B) bacterial cell with a flagellum. (Image credits: Leônidas Leoni Belan, Eduardo Alves and Edson A. Pozza, 2014).
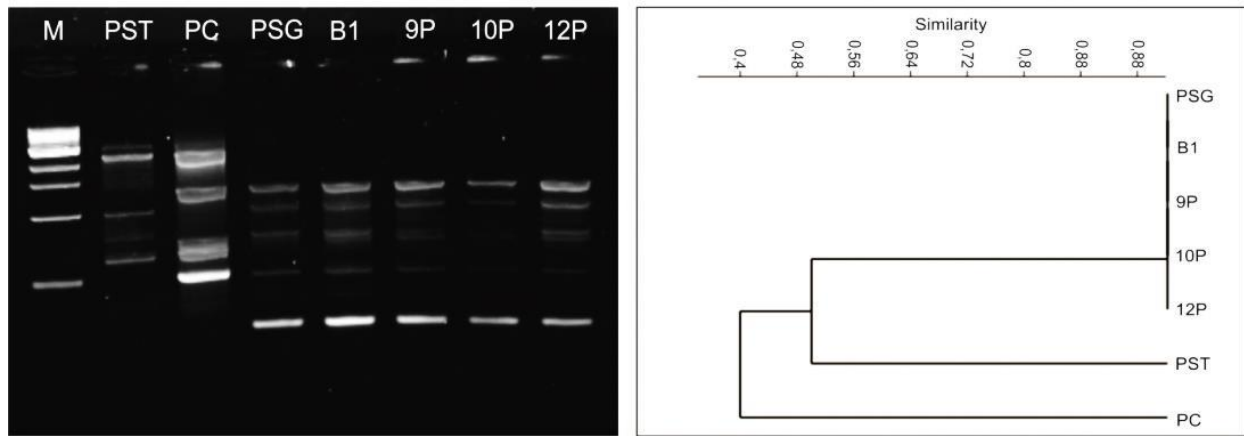

Fig 3. Products of Box-PCR (polymerase chain reaction) and dendrogram of the similarities generated according to profile amplifications from the primer 1 AIR BOX, based on the unweighted pair group method with arithmetic mean (UPGMA method), using the Dice coefficient of similarity of bacterial isolates from coffee seeds and reference isolates of genus Pseudomonas. PST, PC and PSG: respectively, isolates Pseudomonas syringae pv. tabaci (IBSBF 2249), P. cichorii strain pathotype (CFPB 2101) and P. syringae $p v$. garcae strain pathotype (CFPB 1634) used as reference standards. B1, 9P, 10P and 12P: bacterial isolates from coffee seeds (Coffea arabica L.). M: marker of $1 \mathrm{~kb}$. 
These symptoms were similar to those developed by leaves inoculated with reference isolate PSG (CFPB1634) (Fig. 1 B), whereas seedlings inoculated with seed extract of asymptomatic plants had no symptoms (Fig. 1 A). Symptoms were small irregular lesions with water-soaked tissue around the inoculation point. The water-soaked area increased over time and developed a yellow halo around the lesions, characteristic of bacterial blight of coffee. Control plants inoculated with sterile saline remained healthy.

\section{Confirmation the bacterial origin of disease}

The bacterial origin of the disease was demonstrated using exudate tests with the etiologic agent being isolated. Isolation from inoculated symptomatic leaves resulted in colonies morphologically similar to reference isolate PSG, one of the standards of comparison utilized (PSG, PC and PST). As bacterial colonies were morphologically similar to the reference isolate PSG, we selected 13 candidate isolates. Colonies were white to cream color with irregular margins, flat, non-viscous, with rod-shaped bacterial cells (Fig. 2). Over time, a brown pigment formed around the colony.

\section{Pathogenicity of the selected isolates}

Among the 13 selected isolates, four (B1, 9P, 10P and 12P) were positive for hypersensitivity reaction. Leaves of tomato, tobacco, kale, and bell peppers developed hypersensitivity reaction (HR) 24 hours after being inoculated with both the respective isolates and reference isolates $\mathrm{PSG}, \mathrm{PC}$ and PST, proving their pathogenicity (Table 1 ). Isolates with negative reaction for hypersensitivity, or non-pathogenic, were discarded. Confirming the pathogenicity of isolates B1, 9P, $10 \mathrm{P}$, and $12 \mathrm{P}$, only leaves of coffee seedlings inoculated with the respective suspensions reproduced the symptoms of bacterial blight previously described for plants inoculated with seed crude extract, as well as the symptoms induced by reference isolate PSG (Table 1 and Fig. 1).

\section{Biochemical and molecular characterization of the selected isolates}

Biochemically, candidate isolates and reference isolates PSG, PST and PC are Gram-negative, strictly aerobic organisms which produce fluorescent pigment when exposed to ultraviolet light (Table 1). These isolates (B1, 9P, 10P, and 12P) are similar to reference isolates PSG and PST with regard to negative oxidase reaction and positive gelatin hydrolysis; however, they differ from reference isolate PC (positive oxidase and negative gelatin hydrolysis) (Table 1). In addition to biochemical characteristics (Table 1), molecular patterns of isolates from coffee seeds were equal to those of reference isolate PSG, but different from isolate PST (Fig. 3). Box-PCR reaction products of these isolates matched PSG reaction products, differing from reference isolates PC and PST (Fig. 3). The isolates were classified as species $P$. syringae pv. garcae and placed in the collection of bacterial cultures at the Laboratory of Bacteriology, Department of Plant Pathology, Federal University of Lavras, Lavras, Minas Gerais - Brazil.

\section{Discussion}

Inoculation of seed extract from infected plants in coffee leaves resulted in symptoms of bacterial blight of coffee; however, inoculation of seed extract from asymptomatic plants showed no symptoms as there was no seed contamination with inoculum from external sources after harvesting, processing, and storage. Thus, seed-borne bacteria from infected mother plants were responsible for the symptoms. Similarly, Parashar and Leben (1972) used apparently healthy soybean seeds (Glycine max (L.) Merrill) harvested from plantations containing plants infected by $P$. syringae pv. glycinea, and also reported symptoms of this disease in plants derived from these seeds, when exposed to ideal conditions for infection. Thus, even if the pathogen cannot be visually detected in seeds, as occurred in this study, seeds can be effective in disseminating plant bacterial diseases (Parashar and Leben, 1972; Silva et al., 2002; Romeiro, 2005; Corrêa et al., 2008; Silva et al., 2013).

These results show that coffee seeds collected from symptomatic plants can harbor $P$. syringae pv. garcae and contribute to spreading the pathogen. Seeds in general provide optimal conditions for the survival and spread of plant bacteria, which may remain viable for variable periods (Schuster and Sayre, 1967; Silva et al., 2002; Romeiro, 2005; Corrêa et al., 2008). Moreover, seed-borne bacteria can be efficiently disseminated over long distances and introduced in areas free of disease or serve as a source of initial inoculum for epidemics in nurseries and fields (Neergaard, 1979; Romeiro, 2005).

The biochemical patterns of the four bacterial isolates (B1, 9P, 10P, and 12P) pathogenic to coffee were similar to those of reference isolate PSG. They are strictly aerobic, Gramnegative, and grow well in King B culture medium at $28^{\circ} \mathrm{C}$ (King et al., 1954; Powers, 1995). Colonies are white to cream-colored with irregular margins and rod-shaped cells, and move by polar flagella (Lelliott et al., 1966; Rodrigues Neto et al., 1981; Korobko and Wondimagegne, 1997; Moore et al., 2006; Zoccoli et al., 2011; Rodrigues et al., 2013). P. syringae pv. garcae fits group I of fluorescent bacteria, is positive for gelatin hydrolysis and hypersensitivity on tobacco and is negative for oxidase (Lelliott et al., 1966; Rodrigues Neto et al., 1981; Bradbury, 1986; Schaad et al., 2001; Barta and Willis, 2005; Zoccoli et al., 2011). Brazilian isolates produce little fluorescent pigment in King B medium and brown non-fluorescent pigment resulting from melanin production. As this pigment is diffusible in King B medium, it causes medium darkening (Kairu, 1997; Barta and Willis, 2005). Regarding pathogenicity, several species of genus Coffea are natural hosts for $P$. syringae pv. garcae (Bradbury, 1986).

With regard to molecular characterization, the four selected isolates (B1, 9P, 10P, and 12P) had similar standards to those of reference isolate PSG (CFPB1634). The rep-PCR technique used for comparison is internationally recognized and applied to characterize bacterial strains (Koeuth et al., 1995; Louws et al., 1998; Tacão et al., 2005; Hungria et al., 2008; Marques et al., 2008). It consists of determining DNA profile by amplifying DNA sequences using primers (oligonucleotides) related to conserved repetitive sequences usually within the intergenic space (De Bruijn, 1992; Versalovic et al., 1994). In this study we used Box primer (Koeuth et al., 1995). Among families of repetitive elements in the genome, the box A subunit is conserved in bacteria (Koeuth et al., 1995). Thus, Hungria et al. (2008) used and recommended this technique for comparing genetic material from bacterial collections; and Marques et al. (2008) demonstrated that Box-PCR is able to identify bacterial strains at species level. In this study the Box-PCR technique detected differences between PST and PSG, pathovars of the $P$. syringae species, not demonstrated in the other tests (biological and biochemical). Moreover, it was possible to classify bacterial isolates due to similarities with the 
molecular patterns of PSG strain pathotype (CFPB1634), which is the reference of species $P$. syringae pv. garcae.

The PSG was isolated from coffee seedlings inoculated with seed extract, confirming the presence of this pathogen in the propagative material. This is the first report about the occurrence of $P$. syringae $p v$. garcae in coffee seeds. Further studies are needed to understand the bacterial transmissibility from seed to coffee seedling, the relationship between amount of PSG inoculum and its location in coffee seeds, and the effects of this interaction. In addition, due to the possibility that seeds are the origin of the initial inoculum of the disease, the management of bacterial blight in the nursery should initially be preventive, based on seed health, while management in coffee plantations for seed production should focus on the protection of plants against infection.

\section{Materials and Methods}

\section{Plant material: coffee seeds}

We used seeds from two coffee plantations (Coffea arabica L.) with symptoms of bacterial blight of coffee ( $P$. syringae pv. garcae) (Pozza et al., 2010). In both plantations, leaves with symptoms of the disease were collected, the etiologic agent was isolated in 523 medium (Kado and Heskett, 1970), identified by biochemical and molecular patterns (rep-PCR), and classified as $P$. syringae (Raimundi, 2014). The plantations, L1 and L2, are located in Santo Antônio do Amparo, state of Minas Gerais - Brazil, respectively at $20^{\circ}$ 53'23.7"(South) and 44 52'56.9"(West), 20 53'33.9"(South) and $44^{\circ} 52^{\prime} 58^{\prime \prime}(\mathrm{West})$, and are composed of four-year-old Catucaí Amarelo 2SL and five-year-old Catuaí Vermelho IAC 99 cultivars, respectively.

Symptomatic and asymptomatic plants located at distant points in each coffee plantation were marked. In these plants, ripe fruits were picked in June 2013 and mechanically peeled. Seeds were dried in the shade up to $15 \%$ moisture, then placed in paper bags and stored in cold chamber $\left(10^{\circ} \mathrm{C}\right.$ and $50 \%$ relative humidity) (Silva et al., 2010) for 20 days until further use. Four lots were set as follows: Lot 1: seeds of symptomatic plants from plantation L1; Lot 2: seeds of asymptomatic plants from plantation L1; Lot 3: seeds of symptomatic plants from plantation L2; and Lot 4: seeds of asymptomatic plants from plantation L2.

\section{Crude extract of seeds}

Four sub-samples with 100 seeds no macerated were taken from each lot, placed in sterilized erlenmeyer flasks $(250 \mathrm{~mL})$ and immersed in sterilized saline $(0.85 \% \mathrm{NaCl}), 100 \mathrm{~mL}$ per 100 seeds. Then, samples of seeds no macerated in saline were stored for 18 hours at $4^{\circ} \mathrm{C}$, and the crude extracts (supernatant from the flask) were used to inoculate coffee seedlings (Brasil, 2009).

\section{Inoculation of seed crude extract in coffee seedlings}

We inoculated the first two pairs of fully expanded leaves of seedlings from cultivar Catuaí Vermelho IAC 99 (susceptible control) (Ito et al., 2008), produced in organo-mineral substrate (soil, sand and bovine manure - proportion 3:2:1). A set of ten needles fixed on a sturdy surface (multi-needle set) was immersed in the respective seed crude extracts to perform two inoculation points per leaf. With the multineedle set, seedlings were inoculated with sterilized saline (negative control) and inoculum suspension $\left(1.1 \times 10^{9}\right.$ $\mathrm{CFU} / \mathrm{mL}$ ) of strain pathotypes of $P$. syringae pv. garcae
(CFPB1634) (PSG), P. cichorii (CFPB 2101) (PC) and $P$. syringae pv. tabaci (IBSBF 2249) (PST) as standard symptoms. These species are described in the literature causing symptoms in coffee (Robbs et al., 1974; Rodrigues Neto et al., 2006; Destefano et al., 2010). Non-inoculated plants served as absolute controls. The trial was conducted in a plant growth chamber $\left(23 \pm 3^{\circ} \mathrm{C}\right.$, relative air humidity > $70 \%$ and 12-hour light photoperiod) in randomized blocks with four replicates, each experimental unit consisting of three seedlings. Results were deemed positive for leaves with visual symptoms of disease similar to those developed by leaves inoculated with reference isolates PSG, PC and/or PST.

\section{Isolation of the etiologic agent}

Ten days after inoculation, leaves of coffee seedlings that had developed symptoms of bacterial blight were collected and submitted to an exudate test to confirm the bacterial origin of disease. In positive cases (bacterial fluid flowing out of the diseased tissue to water), the etiologic agent was isolated (direct isolation) in 523 medium (Kado and Heskett, 1970). PSG, PC and PST isolates were subcultured onto 523 medium for comparing colony morphology. Plates were incubated at $28^{\circ} \mathrm{C}$ for $24-48 \mathrm{~h}$ and colony morphology was compared with reference isolates. Colonies morphologically similar to PSG, PC or PST isolates (candidate isolates) were subcultured in tubes containing 523 medium, incubated at $28^{\circ} \mathrm{C}$ for 24 hours and then stored at $4^{\circ} \mathrm{C}$. The morphological characteristics of the isolated colonies were observed, such as color, shape, viscosity and the presence of bacterial halo and its color. The morphological characteristics of the bacterial cells were analyzed by transmission electron microscopy of leaf dip preparations, stained with uranyl acetate.

\section{Hypersensitivity reaction to prove pathogenicity}

Candidate isolates were transferred to test tubes containing 523 medium and incubated at $28^{\circ} \mathrm{C}$ for 24 hours. Subsequently, inoculum suspension $\left(1 \times 10^{8} \mathrm{CFU} / \mathrm{mL}\right)$ from each isolate was prepared using sterile saline $(0.85 \% \mathrm{NaCl})$. The suspension was injected with a sterile hypodermic syringe into leaves of tobacco (Nicotiana tabacum L.), tomato (S. lycopersicum L.), bell pepper (Capsicum annuum L.), and kale (Brassica oleracea L.). PSG (CFPB 1634), PC (CFPB 2101) and PST (IBSBF 2249) isolates were inoculated as reference standards. The plants were kept in a plant growth chamber at $23 \pm 3^{\circ} \mathrm{C}$, relative air humidity > $70 \%$ and 12-hour light photoperiod. At 24 hours after inoculation we assessed the occurrence of hypersensitivity reaction (HR) symptoms.

To confirm the pathogenicity of isolates, coffee seedlings of Catuaí Vermelho IAC 99 cultivar with four pairs of leaves were inoculated with suspension from each candidate isolate. Inoculum was injected into the first two pairs of fully developed leaves, performing two inoculation points per leaf. Two seedlings were inoculated per isolate. Leaves of coffee seedlings with symptoms of bacterial blight were collected and submitted to an exudate test to confirm the bacterial origin of the disease. The etiologic agent was re-isolated in 523 medium.

Gram stain reaction, biochemical and molecular tests for identifying plant bacteria

Bacterial isolates positive for HR reaction and pathogenic to coffee were biochemically characterized according to Lelliott 
et al. (1966), Wilkie and Dye (1974), Rodrigues Neto et al. (1981), Schaad et al. (2001) and Maringoni (2010), and also by molecular assays (De Bruijn, 1992; Versalovic et al., 1994; Koeuth et al., 1995). We used the following tests: Gram stain based on $\mathrm{KOH}$ solubility, anaerobiosis, oxidase, gelatin hydrolysis, fluorescent pigment production on King B medium, and rep-PCR using Box primer. Strain pathotypes of PSG (CFPB 1634), PC (CFPB 2101) and PST (IBSBF 2249) were used as reference patterns.

\section{Gram stain}

Bacterial colonies with morphology and color similar to $P$. syringae pv. garcae were subjected to Gram stain according to the KOH test proposed by Ryu (1940), (Moran and Upton, 1986; Powers, 1995; Schaad et al., 2001). The technique consists of smearing bacterial colonies on a glass slide containing 4-5 drops of $\mathrm{KOH}$ solution (3.5\%), homogenizing it with a platinum loop and checking for a gelatinous thread forming between the loop and the slide. The isolate was deemed gram-negative when the preparation turned viscous (Ryu, 1940; Powers, 1995).

\section{Anaerobiosis}

Candidate isolates were cultured in 523 liquid medium at $28^{\circ} \mathrm{C}$ for 24 hours. Subsequently, $100 \mu \mathrm{L}$ of culture medium were transferred to petri dishes containing 523 medium and spread on the surface with Drigalski spatula. A sterile glass coverslip was placed in the center of each plate and placed in incubator at $28^{\circ} \mathrm{C}$ for $24 \mathrm{~h}$. Bacterial isolates that did not grow under the coverslip were considered strictly aerobic (Schaad et al., 2001; Maringoni, 2010).

\section{Oxidase test}

Candidate isolates were cultured in 523 medium at $28^{\circ} \mathrm{C}$ for 24 hours. Strips of filter paper were wetted in a freshly prepared solution of tetramethyl-p-phenylenediamine dihydrochloride $(1 \%)$. A portion of bacterial growth was transferred to the moistened paper with a platinum loop. The result was deemed positive if the paper showed purple color after 10 seconds, and negative if it remained white after 60 seconds (Schaad et al., 2001).

\section{Gelatin hydrolysis}

Test tubes were prepared with $5 \mathrm{ml}$ gelatin medium (beef extract $3 \mathrm{~g}$, peptone $5 \mathrm{~g}$, unflavored gelatin $120 \mathrm{~g}$, and distilled water 1 L) (Maringoni, 2010). Bacterial isolates were subcultured by puncturing the medium with a platinum spatula (three tubes per isolate). Control treatment consisted of three tubes containing non-inoculated culture medium. Tubes were incubated at $28^{\circ} \mathrm{C}$ and evaluation was performed 21 days after inoculation. Before testing, tubes were stored at $4^{\circ} \mathrm{C}$ for 30 minutes. Isolates were deemed positive for gelatin hydrolysis if the medium remained liquid after refrigeration (Schaad et al., 2001).

\section{Pigment production on King B medium}

This test differentiates bacteria of the genus Pseudomonas spp. as belonging to the fluorescent or non-fluorescent group (Schaad et al., 2001). Culture medium was composed of $20 \mathrm{~g}$ peptone, $1.5 \mathrm{~g} \mathrm{~K}_{2} \mathrm{HPO}_{4}, 1.5 \mathrm{~g} \mathrm{MgSO}_{4}, 15 \mathrm{ml}$ glycerol, $15 \mathrm{~g}$ agar, and $1 \mathrm{~L}$ distilled $\mathrm{H}_{2} \mathrm{O}$. We placed approximately $10 \mathrm{~mL}$ of medium in each petri dish. The inoculum of each isolate was seeded in streaks on medium surface with an inoculation loop and placed in incubator at $28^{\circ} \mathrm{C}$ for 48 hours. A dish containing non-inoculated King B medium was subjected to the same conditions. The isolates capable of producing fluorescent pigment turned the medium to a fluorescent green color under ultraviolet light, and thus were considered positive. Otherwise, the result was negative. Pigment production was compared with the control.

\section{Molecular assays - Analysis of genetic diversity using Box-} PCR

\section{DNA extraction}

Total genomic DNA extraction was performed using the modified protocol of Ausubel et al. (1994). Aliquots of $1.5 \mathrm{ml}$ bacterial suspensions from each isolate, cultured under stirring for $24 \mathrm{~h}$ at $28^{\circ} \mathrm{C}$ in 523 liquid medium (Kado and Heskett, 1970), were centrifuged at $10,000 \mathrm{rpm}$ for 10 seconds at $4^{\circ} \mathrm{C}$. The supernatant was discarded and the pellet resuspended in $567 \mu \mathrm{l}$ TE buffer $(10 \mathrm{mM}$ tris- $\mathrm{HCl}, \mathrm{pH} 7.6,1$ $\mathrm{mM}$ EDTA), $30 \mu \mathrm{l} \mathrm{SDS} \mathrm{(10 \%} \mathrm{g/v)} \mathrm{and} 3 \mu \mathrm{l}$ proteinase K (20 $\mathrm{mg} / \mathrm{ml}$ ) followed by manual shaking. Tubes were kept partially immersed in warm water $\left(37^{\circ} \mathrm{C}\right)$ for 1 hour and 100 $\mu \mathrm{L}$ of $5 \mathrm{M} \mathrm{NaCl}$ were added to tube contents, followed by vortexing. Then $80 \mu \mathrm{lCTAB} / \mathrm{NaCl}$ solution $(4.1 \mathrm{~g} \mathrm{NaCl}$ and $10 \mathrm{~g}$ CTAB in $100 \mathrm{ml}$ water) was added, followed by vortexing. Tubes were incubated when partially immersed in warm water $\left(65^{\circ} \mathrm{C}\right)$ for 10 minutes and then at room temperature $\left(25^{\circ} \mathrm{C}\right)$. We added $780 \mu \mathrm{l}$ chloroform: isoamyl alcohol $24: 1$ followed by manual shaking for 10 minutes and centrifugation at $12,000 \mathrm{rpm}$ for 5 minutes at $4^{\circ} \mathrm{C}$. After this process, the upper phase was transferred to a new tube and volume $(500 \mu \mathrm{l})$ was measured. Then we added $300 \mu \mathrm{l}$ isopropyl alcohol and mixed until DNA precipitated. Centrifugation was performed at $12,000 \mathrm{rpm}$ for 2 minutes. The supernatant was removed and the pellet washed with 1 $\mathrm{ml}$ of $70 \%$ ethanol, followed by centrifugation at 12,000 rpm for 5 minutes and subsequent disposal of $70 \%$ ethanol. The pellet was resuspended in $60 \mu \mathrm{TE}$ buffer and stored at $-20^{\circ} \mathrm{C}$.

\section{Box-PCR}

Gene identification of isolates from coffee seeds was performed by rep-PCR technique using Box primer (BoxAlR 5'-CTAC GGCAAGGCGACGCTGACG-3' (Koeuth et al., 1995). Reaction was performed with $25 \mu \mathrm{L}$ containing $2.5 \mu \mathrm{L}$ 10X Taq buffer, $1.2 \mu \mathrm{L}$ of $25 \mathrm{mM} \mathrm{MgCl} 2,0.5 \mu \mathrm{L}$ dNTPs (10 $\mathrm{mM}), \quad 0.5 \mu \mathrm{L}$ primer, $2.5 \mathrm{U}$ of Taq DNA polimerase (Fermentas), $2 \mu \mathrm{L}$ DNA, and $18 \mu \mathrm{L}$ nuclease-free water.

Amplification was performed in Axygen ${ }^{\circledR}$ MaxyGene ${ }^{\mathrm{TM}}$ thermal cycler Therm 1000 in the following steps: initial denaturation at $95^{\circ} \mathrm{C}$ for $2 \mathrm{~min} ; 30$ cycles consisting of denaturation at $95^{\circ} \mathrm{C}$ for $30 \mathrm{sec}$, annealing for $1 \mathrm{~min}$ at $52^{\circ} \mathrm{C}$, and extension at $72^{\circ} \mathrm{C}$ for $5 \mathrm{~min}$ with a final extension cycle at $72^{\circ} \mathrm{C}$ for $5 \mathrm{~min}$.

The amplified products were visualized on $1.5 \%$ agarose gel in 1X TBE buffer and stained with GelRed Nucleic Acid Gel Stain (Biotium $\left.{ }^{\circledR}\right)$. We used marker $1 \mathrm{~Kb}$ DNA Ladder (Gibco BRL) and PSG, PC and PST isolates as reference standards. The similarity matrix was constructed using the Dice coefficient. The dendrograms were obtained using the unweighted pair group method with arithmetic mean algorithm (UPGMA method). 


\section{Conclusion}

Coffee seeds from plants with symptoms of bacterial blight of coffee can contain viable inoculum of $P$. syringae pv. garcae. Due to this fact, the management of bacterial blight in a nursery for coffee seedlings should initially be preventive, based on seed health, and in coffee plantations for seed production there should be additional protection of plants against infection.

\section{Acknowledgements}

We thank the Foundation for Research Support of the State of Minas Gerais (FAPEMIG), the Coordination for the Improvement of Higher Education Personnel (CAPES), the National Council for Scientific and Technological Development $(\mathrm{CNPq})$ and the National Institute of Science and Technology of Coffee (INCT-Café) for contributing to the research and for granting scholarships to the first author.

\section{References}

Amaral F, Teixeira C, Pinheiro E (1956) A bacterium causing halo blight of coffee. Arq Inst Biol. 23:151-155.

Ausubel F, Brent R, Kingston R, Moore D, Seidman J, Smith J, Struhl K (1994) Current protocols in molecular biology. Wiley Interscience, New York. 337 p.

Bacilio-Jiménez M, Aguilar-Flores S, Del Valle M, Pérez A, Zepeda A, Zenteno E (2001) Endophytic bacteria in rice seeds inhibit early colonization of roots by Azospirillum brasilense. Soil Biol Biochem. 33:167-172.

Barta T, Willis D (2005) Biological and molecular evidence that Pseudomonas syringae pathovars coronafaciens, striafaciens and garcae are likely the same pathovar. J Phytopathol. 153:492-499.

Bradbury JF (1986) Guide to plant pathogenic bacteria. CAB international, Minnesota. $332 \mathrm{p}$.

Brasil (2009) Manual de Análise Sanitária de Sementes. Ministério da Agricultura, Pecuária e Abastecimento / Secretaria de Defesa Agropecuária., Brasília. 200 p.

Carmo M, Maffia L, Kimura O, Carvalho A (1996) Disseminação da pústula bacteriana do pimentão, causada por Xanthomonas campestris pv. vesicatoria, em condições de viveiro. Fitopatol Bras. 20:85-93.

Carmo MGFD, Correa FM, Cordeiro ES, Carvalho ADOD, Rossetto CA (2004) Tratamentos de erradicação de Xanthomonas vesicatoria e efeitos sobre a qualidade das sementes de tomate. Hortic Bras. 22:579-584.

Corrêa FM, Carvalho ADOD, Carmo MGFD (2008) Inoculação e sobrevivência de Xanthomonas vesicatoria em sementes de tomateiro. Summa Phytopathol. 34:71-75.

De Bruijn FJ (1992) Use of repetitive (repetitive extragenic palindromic and enterobacterial repetitive intergeneric consensus) sequences and the polymerase chain reaction to fingerprint the genomes of Rhizobium meliloti isolates and other soil bacteria. Appl Environ Microb. 58:2180-2187.

Destefano S, Rodrigues L, Beriam L, Patricio F, Thomaziello R, Rodrigues-Neto J (2010) Bacterial leaf spot of coffee caused by Pseudomonas syringae pv. tabaci in Brazil. Plant Pathol. 59:1162-1163.

Goto M (2012) Fundamentals of bacterial plant pathology. Academic Press, San Diego. 342 p.

Guthrie J (1970) Factors influencing halo blight transmission from externally contaminated Phaseolus vulgaris seed. Phytopathology. 60:371-372.

Hungria M, Chueire L, Menna P, Bangel E (2008) Caracterização genética de rizóbios e outras bactérias diazotróficas e promotoras do crescimento de plantas por BOX-PCR. Embrapa Soja, , Londrina. 12 p.

Ito DS, Sera T, Sera G, Del Grossi L, Kanayama F (2008) Resistance to bacterial blight in arabica coffee cultivars. Crop Breed Appl Biot. 8:99-103.

Jones JB, Lacy GH, Bouzar H, Stall RE, Schaad NW (2004) Reclassification of the Xanthomonas associated with bacterial spot disease of tomato and pepper. Syst Appl Microbiol. 27:755-762.

Kado C, Heskett M (1970) Selective media for isolation of Agrobacterium, Corynebacterium, Erwinia, Pseudomonas and Xanthomonas. Phytopathology. 60:969-976.

Kairu GM (1997) Biochemical and pathogenic differences between Kenyan and Brazilian isolates of Pseudomonas syringae pv. garcae. Plant Pathol. 46:239-246.

King EO, Ward MK, Raney DE (1954) Two simple media for the demonstration of pyocyanin and fluorescin. J Lab Clin Med. 44:301-307.

Koeuth T, Versalovic J, Lupski J (1995) Differential subsequence conservation of interspersed repetitive Streptococcus pneumoniae box elements in diverse bacteria. Genome Res. 5:408-418.

Korobko A, Wondimagegne E (1997) Bacterial blight of coffee (Pseudomonas syringae pv. garcae) in Ethiopia. In: Rudolph K, Burr TJ, Mansfield JW et al. (ed) Pseudomonas Syringae Pathovars and Related Pathogens. Springer, New York.

Lelliott R, Billing E, Hayward A (1966) A determinative scheme for the fluorescent plant pathogenic Pseudomonas. J Appl Bacteriol. 29:470-489.

Louws F, Bell J, Medina-Mora C, Smart C, Opgenorth D, Ishimaru C, Hausbeck M, De Bruijn F, Fulbright D (1998) Rep-PCR-mediated genomic fingerprinting: a rapid and effective method to identify Clavibacter michiganensis. Phytopathology. 88:862-868.

Maringoni A (2010) Técnicas em fitobacteriologia. Fepaf, Botucatu. $70 \mathrm{p}$.

Marques A, Marchaison A, Gardan L, Samson R (2008) BOX-PCR-based identification of bacterial species belonging to Pseudomonas syringae: P. viridiflava group. Genet Mol Biol. 31:106-115.

Moore ER, Tindall BJ, Dos Santos VaM, Pieper DH, Ramos J-L, Palleroni NJ (2006) Nonmedical: Pseudomonas. In: Dworkin M, Falkow S, Rosenberg E, KH S and Stackebrandt E (ed) The Prokaryotes. Springer, New York.

Moran A, Upton ME (1986) A comparative study of the rod and coccoid forms of Campylobacter jejuni ATCC 29428. J Appl Bacteriol. 60:103-110.

Neergaard P (1979) Seed pathology. MacMillan Press London. $839 \mathrm{p}$.

Nelson EB (2004) Microbial dynamics and interactions in the spermosphere. Annu Rev Phytopathol. 42:271-309.

Parashar R, Leben C (1972) Detection of Pseudomonas glycinea in soybean seed lots. Phytopathology. 62:10751077.

Powers EM (1995) Efficacy of the Ryu nonstaining KOH technique for rapidly determining gram reactions of foodborne and waterborne bacteria and yeasts. Appl Environ Microb. 61:3756-3758.

Pozza E, Carvalho V, Chalfoun S (2010) Sintomas e injúrias causadas por doenças em cafeeiro. In: Guimarães R, Mendes A and Baliza D (ed) Semiologia do cafeeiro: sintomas de desordens nutricionais, fitossanitárias e fisiológicas. Edit UFLA, Lavras.

Raimundi M (2014). Caracterização e identificação de isolados bacterianos patogênicos ao cafeeiro. Master's degree Dissertation, 79p. Federal University of Lavras. 
Robbs C, Kimura O, Ribeiro R, Oyadomori L (1974) Crestamento bacteriano das folhas": nova enfermidade do cafeeiro (Coffea arabica L.) incitada por Pseudomonas cichorii (Swingle) Stapp. Arq Univ Fed Rural Rio J. 4:1-5.

Rodrigues LMR, Almeida IMG, Patrício FRA, Beriam LOS, Maciel KW, Braghini MT, Guerreiro Filho O (2013) Mancha aureolada do cafeeiro causada por Pseudomonas syringae pv. garcae. Instituto Agronômico, Campinas - SP. 24.

Rodrigues Neto J, Figueiredo PM, P.R., Robbs CF (1981) Pseudomonas andropogonis (Smith, 1911) Stapp, 1928, agente causal da "mancha escura bacteriana" em folhas de cafeeiro (Coffea arabica L.). Arq Inst Biol. 48:31-36.

Rodrigues Neto J, Silva CHD, Beriam LOS, Patrício FRA, Rodrigues LMR, Thomazielo RA (2006) Mancha bacteriana do cafeeiro causada por Pseudomonas syringae pv. tabaci. Summa Phytopathol. 32.

Romeiro RDS (2005) Bactérias fitopatogênicas. Ed. UFV, Viçosa. 417 p.

Ryu E (1940) A simple method of differentiation between gram-positive and gram-negative organisms without staining. Kitasato Arch Exp Med. 17:58-63.

Saettler A, Schaad N, Roth D (1989) Detection of bacteria in seed and other planting material. American Phytopathological Society Press, St. Paul. 122 p.

Schaad N, Jones J, Chun W (2001) Laboratory guide for identification of plant pathogenic bacteria. American Phytopathological Society Press, St Paul. 373 p.

Schuster M, Sayre R (1967) A coryneform bacterium induces purple-colored seed and leaf hypertrophy of Phaseolus vulgaris and other leguminosae. Phytopathology. 57:10641066.
Silva A, Carmo MG, Olivares FL, Pereira AJ (2002) Termoterapia via calor seco no tratamento de sementes de tomate: eficiência na erradicação de Xanthomonas campestris $p v$. vesicatoria e efeitos sobre a semente. Fitopatol Bras. 27:586-593.

Silva DA, De Carvalho ADO, Pereira MB, Olivares FL, Do Carmo MGF (2013) Transporte de Xanthomonas vesicatoria de sementes para plântulas e mudas de tomate. Hortic Bras. 31:50-58.

Silva EMD, Rezende JCD, Nogueira ÂM, Carvalho GR (2010) Produção de mudas de cafeeiro In: Reis PR and Cunha RLd (ed) Café arábica do plantio à colheita. EPAMIG, Lavras.

Simon HM, Smith KP, Dodsworth JA, Guenthner B, Handelsman J, Goodman RM (2001) Influence of tomato genotype on growth of inoculated and indigenous bacteria in the spermosphere. Appl Environ Microb. 67:514-520.

Tacão M, Alves A, Saavedra M, Correia A (2005) BOX-PCR is an adequate tool for typing Aeromonas spp. Anton Leeuw Int J G. 88:173-179.

Versalovic J, Schneider M, De Bruijn FJ, Lupski JR (1994) Genomic fingerprinting of bacteria using repetitive sequence-based polymerase chain reaction. Method Mol Cell Biol. 5:25-40.

Wilkie P, Dye D (1974) Pseudomonas cichorii causing tomato and celery diseases in New Zealand. New Zeal J Agr Res. 17:123-130.

Zoccoli DM, Takatsu A, Uesugi CH (2011) Ocorrência de mancha aureolada em cafeeiros na região do triângulo mineiro e alto paranaíba. Bragantia. 70:843-849. 